УДК 378.4.091.33:81'27

DOI: https://doi.org/10.33989/2075-146x.2019.23.183213

\title{
ТЕТЯНА ІСАЄНКО
}

\section{ОЛЬГА МІЗІНА}

Полтавський національний технічний університет імені Юрія Кондратюка

\section{УДОСКОНАЛЕННЯ МОВНОЇ ТА КОМУНІКАТИВНОЇ КОМПЕТЕНТНОСТЕЙ МАЙБУТНІХ ФАХІВЦІВ}

У статті розкриті й проаналізовані шляхи удосконалення мовної та комунікативної компетентностей майбутніх фахівців у вищій школі. Обгрунтовується i набуває методичної інтерпретації положення, що на сучасному етапі розвитку суспільства важливо сформувати успішну, освічену людину, здатну ухвалювати відповідальні рішення, критично мислити, творчо виконувати виробничі завдання - тобто особистість з високим рівнем мовної та комунікативної компетентності, яка володіє сукупністю знань, умінь і навичок, що забезпечить бездоганне виконання професійних обов'язків, потребу в самопізнанні, саморозвитку, самореалізації, уміння об'єктивно розв'язувати життєві проблеми, соціально адаптуватися.

Ключові слова: професіограма фахівця; мовна компетентність; комунікативна компетентність; вищі заклади освіти; навчальний процес

Постановка проблеми. Мовні проблеми завжди будуть актуальними і вимагатимуть кардинальних змін для покращення ситуації в суспільстві щодо практичного застосування цього унікального засобу людського спілкування. Прийнято вважати, що говорити правильно, тобто 3 дотриманням усіх літературних норм, повинні тільки керівники, високопосадовці, публічні люди, учителі. Навіть побутує думка, що це обов'язок філолога, а вчителю математики, хімії чи фізики не обов'язково перейматися такими проблемами. Пересічні люди дозволяють собі недбалість у використанні мовних засобів як на робочому місці, виконуючи свої професійні обов'язки, так і в побуті. Завдання сучасної вищої школи підготувати не тільки кваліфікованого фахівця, а сформувати інтелектуальну особистість 3 високою моральною культурою, одним із найважливіших показників якої, на нашу думку, є досконале володіння літературною мовою, тобто досягнення високого рівня мовної та комунікативної компетентності.

Аналіз досліджень та публікацій. У наукових розвідках багатьох учених знайшли відображення проблеми формування мовної, мовленнєвої та комунікативної компетентностей майбутніх фахівців у навчальному процесі (Н. Бабич, М. Вашуленко, О. Корніяка, Н. Ларіна, С. Мартиненко, Л. Мацько, Л. Паламар, М. Пентилюк та ін.), удосконалення професійного мовлення (І. Гуменна, Ю. Вторнікова, О. Муромцева, В. Жовтобрюх, Л. Струганець). Науковцями активно обговорюється проблема формування культури ділового мовлення фахівців різних галузей (Л. Барановська, М. Зубков, Н. Тоцька, О. Любашенко та ін.), специфіка творчого використання інформації про феномен мови й мовлення (О. Смирницький, А. Супрун, С. Семчинський, Л. Щерба та ін.), особливості публічного мовлення (С. Гуревич, Г. Сагач, Н. Бабич, Б. Головін, І. Шведов, П. Таранов та ін.).

Отже, увага вчених зосереджується на досягненні мовного рівня в усіх його виявах, проте методика реалізації та засоби впровадження в навчальний процес розроблені недостатньо і потребують подальшого дослідження.

Мета статті. Висвітлити шляхи удосконалення мовної та комунікативної компетентностей майбутніх фахівців у вищій школі.

Виклад основного матеріалу. Кожний вищий навчальний заклад, готуючи фахівців різних спеціальностей, керується відповідними професіограмами - найважливішим джерелом інформації про професії. Український тлумачний словник визначає це поняття як науковий опис виду праці та необхідних професійних якостей, що може використовуватись у профорієнтації, підборі кадрів і т. ін.

В організації навчального процесу у вищих закладах освіти, який передбачає як професійно-трудовий, так i навчально-творчий складник, враховується зміст професіограми майбутнього спеціаліста для максимального наближення до сучасних вимог виробництва.

Основними складовими професіограми молодих спеціалістів будь-якої галузі народного господарства, на нашу думку, $є$ такі групи якостей:

- морально-етична стійкість (єдність моральної свідомості й поведінки, сукупність імперативів особистісної і професійної етики згідно з моральними принципами суспільства);

- орієнтованість на наукові основи певної професії (розвинене теоретичне мислення, уміння та потреба вести дослідну роботу); рівня);

- здатність до постійного самовдосконалення, саморозвитку (свідома потреба підвищення кваліфікаційного

- високий рівень мовної та комунікативної компетентності.

Компетенція (від. лат. competencia - коло питань, з якими людина добре обізнана, володіє знаннями і досвідом) - це інтегрований результат опанування змістом вищої освіти, який виражається в готовності студента використовувати засвоєні знання, уміння, навички, а також способи діяльності у конкретних ситуаціях для розв'язання практичних і теоретичних виробничих завдань. 
Володіння людиною відповідною компетенцією позначається терміном «компетентність». Якщо компетенція $є$ наперед заданою нормою освітньої підготовки, то компетентність - це конкретні вміння та навички, необхідні людині будь-якої професії для якісної продуктивної діяльності в певній сфері. Отже, компетентність - динамічна комбінація знань, способів мислення, поглядів, цінностей, навичок, умінь, інших особистих якостей, що визначає здатність особи успішно виконувати професійну діяльність.

Глибоко характеризуючи поняття мовної компетенції, вчені надають перевагу мовній активності, мовному використанню, протиставляючи просто мовним знанням, розглядаючи не як вроджене явище, а як результат процесу соціалізації. Ф. С. Бацевич визначає мовну компетенцію як «знання учасниками комунікацій мови (мовного коду), тобто правил, за якими формуються правильні мовні конструкції та повідомлення, здійснюється їх трансформація» (Бацевич, 2004, с. 123). Мовна компетентність, на нашу думку, передбачає не тільки знання мови, іiі норм, правил та закономірностей функціонування в різних сферах суспільної діяльності, а й володіння фахівцем будь-якої сфери мовними знаннями, тобто розуміти структуру мови, знати особливості їі словникового складу та граматичної будови, правила написання слів та їх використання в різних функціональних стилях, зокрема в офіційно-діловому. Мовна компетентність будь-якого спеціаліста включає знання про функціонування і системну організацію української мови на рівнях лексики, граматики, фонетики і фонології, орфографії, орфоепії, пунктуації.

Комунікативну компетентність учені трактують по-різному. Ф. С. Бацевич визначає це поняття як «сукупність знань про спілкування в різноманітних умовах і з різними комунікантами, а також знань вербальних і невербальних засад інтеракції, умінь їх ефективного застосування конкретному спілкуванні в ролі адресанта й адресанта» (Бацевич, 2004, с. 124). Ми погоджуємося з такими авторами, як I. Гуменна, А. Гуралюк, Н. Ларіна, С. Мартиненко, О. Корніяка, які, досліджуючи цей мовний феномен, вважають його одним із найважливіших складників професійної компетентності спеціаліста та показником сформованості системи професійних знань, комунікативних умінь і навичок, ціннісних орієнтацій, загальної гуманітарної культури, інтегральних показників культури мовлення, необхідних для якісної професійної діяльності. Отже, комунікативна компетентність - це інтегроване поняття, яке поєднує здатність особистості застосовувати знання мови в різних ситуаціях, у яких відбувається мовленнєвий акт відповідно до мети спілкування, а саме: сприймати інформацію і формулювати думку, підтримуючи спілкування у логічному зв'язному руслі відповідно до конкретних комунікативних намірів, та індивідуально-психологічні якості особистості, які впливають на досягнення комунікативної мети. Володіння комунікативною компетентністю дає змогу посадовій особі ефективно виконувати свої службові обов'язки.

Поділяємо думку авторів, які вважають, що явище мовної і комунікативної компетентностей поліаспектне і може бути предметом дослідження не лише мовознавчої, але й інших галузей суспільно-гуманітарної науки. «Психологи, психолінгвісти, дидакти й методисти доводять, що мовна, мовленнєва, комунікативна компетентності - не лише навчальна мета, а й одна 3 визначальних умов оволодіння знаннями на різних освітніх рівнях» (Білогорка, \& Мороз, 2015, с. 223).

Мовні та комунікативні знання, вміння, навички закладаються в дитинстві, набуваються та формуються в загальноосвітніх школах, удосконалюються протягом усього життя. Відомо, що метою повної загальної середньої освіти є всебічний розвиток, виховання і соціалізація особистості, яка здатна до життя в суспільстві й цивілізованої взаємодії з природою, має прагнення до самовдосконалення і навчання впродовж життя, готова до свідомого життєвого вибору та самореалізації, відповідальності, трудової діяльності та громадянської активності. Досягнення цієї мети забезпечується через формування ключових компетентностей, необхідних кожній сучасній людині для їі успішної життєдіяльності.

Відповідно до проекту нового базового Закону України «Про освіту» визначено 10 ключових компетентностей для Нової української школи, першими серед яких є: вільне володіння державною мовою; здатність спілкуватися рідною (у разі відмінності від державної) та іноземними мовами. Це вміння усно і письмово висловлювати й тлумачити поняття, думки, почуття, факти та погляди (через слухання, говоріння, читання, письмо, застосування мультимедійних засобів). Здатність реагувати мовними засобами на повний спектр соціальних і культурних явищ у навчанні, на роботі, вдома, у вільний час. Усвідомлення ролі ефективного спілкування. (Грищенко, 2016).

Спільними для всіх компетентностей $є$ такі вміння: читання з розумінням, уміння висловлювати свою думку усно і письмово, критичне та системне мислення, здатність логічно обгрунтовувати позицію, творчість, ініціативність, вміння конструктивно керувати емоціями, оцінювати ризики, приймати рішення, вирішувати проблеми, здатність співпрацювати з іншими.

Вищі освітні заклади безсумнівно зобов'язані приділяти цьому велику увагу, вести, на нашу думку, не тільки збалансоване, скоординоване удосконалення практичного використання мови, формувати у майбутніх спеціалістів професійно зорієнтовані уміння, навички досконалого володіння українською літературною мовою у фаховій сфері, а й виховувати високоморальних, національно свідомих особистостей. Ми вважаємо, що майбутній спеціаліст, маючи вищу освіту, повинен повною мірою володіти не тільки фаховою мовою як «сукупністю усіх мовних засобів, якими послуговуються у професійно обмеженій сфері комунікації з метою забезпечення порозуміння між людьми, які працюють у цій сфері» (Шевчук, \& Клименко, 2011, с. 17), а послуговуватися державною мовою на високому рівні через внутрішні, глибинні потреби. Це можливо досягти, поставивши за мету готувати свідомих спеціалістів відповідно до складеної професіограми, забезпечуючи виконання всіх ії складових, і в першу чергу побороти байдуже ставлення до свого мовлення, мовну неохайність, невміння й небажання контролювати себе. Вища школа зобов'язана мотивувати студентів виховувати в собі повагу до мови, держави, іiі історії, культури, адже мова не лише засіб спілкування, а й своєрідний генетичний код нації.

Полтавський національний технічний університет імені Юрія Кондратюка $є$ вищим навчальним закладом, який відповідно до ліцензії здійснює підготовку здобувачів вищої освіти більше ніж за сорока спеціальностями.

Зокрема, навчально-науковий інститут фінансів, економіки та менеджменту в складі університету сьогодні здійснює підготовку здобувачів вищої освіти з економіки, фінансів, банківської справи та страхування, обліку й 
оподаткування, менеджменту, публічного управління та адміністрування, маркетингу, підприємництва, торгівлі та біржової діяльності, міжнародних економічних відносин і туризму. Підготовка фахівців з публічного управління та адміністрування дає повноваження університету проводити атестацію осіб, які претендують на вступ на державну службу, щодо вільного володіння державною мовою і право видавати посвідчення встановленого зразка відповідно до затвердженого Постановою Кабінету Міністрів України від 26 квітня 2017 року №301 «Порядку атестації осіб, які претендують на вступ на державну службу, щодо вільного володіння державною мовою». Порядок атестації розроблено на підставі Стандарту української мови для державних службовців. Створення Стандарту української мови для державних службовців є результатом узагальнення досвіду діяльності державної служби в Україні, демократичних країнах Європи і світу, в яких мовне питання є невід’ємним складником державної політики. Цей досвід засвідчує нагальну потребу у використанні працівником державної інституції державної мови (українська мова $\epsilon$ державною мовою України згідно зі ст. 10 «Конституції України») для виконання посадових обов'язків. Необхідний рівень фахової компетентності державного службовця можливий лише за наявності в нього відповідного рівня мовної і комунікативної компетентностей. Тому метою Стандарту є визначення для державного службовця необхідного обсягу мовних та комунікативних знань, умінь і навичок для забезпечення видів фахової діяльності, передбачених «Законом про державну службу».

Відповідно до проекту Стандарту української мови для державних службовців і Порядку атестації осіб, які претендують на вступ на державну службу визначено такі вимоги щодо рівня комунікативної компетентності осіб (знання, володіння, вміння, розрізнення понять) в межах таких тем: стильова природа української ділової мови, ії особливості (точність, нормативність, логічність та ін.), стилістичні норми мови і функції мовних засобів усіх рівнів в офіційно-діловому стилі. Жанрова диференціація ділової мови, структура й основні мовні характеристики жанрів офіційно-ділового стилю. Лексика і фразеологія офіційно-ділового стилю. Специфічні лексикофразеологічні засоби в діловому спілкуванні (номенклатура, професіоналізми, штампи, кліше, стандарти тощо). Формули ввічливості. Лексичні засоби висловлення подяки, вибачення, згоди/незгоди, підтримки, схвалення, сумніву, занепокоєння, заперечення, попередження і т. ін. Мовні засоби формулювання думки, зокрема тези, антитези, мети, завдань, висновків і т. ін. у текстах публічних виступів. Стилістичні особливості словотвору, специфіка побудови простих, складних і ускладнених речень, форм звертання тощо. Лінгвістичні особливості жанрів за критерієм функціонального призначення. Канцелярський підстиль: організаційні документи (положення, статут, інструкція, правила), розпорядчі, довідково-інформаційні тексти (довідка, лист, записка, акт, звіт, оголошення, протокол, подання, план роботи), кадрова та особова документація. Законодавчий підстиль (конституція, закон, кодекс, постанова, указ). Дипломатичний підстиль: документи у сфері внутрішньовідомчої діяльності та міжнародних відносин (нота, меморандум, ком’юніке, декларація, заява, відозва).

Такий стандарт, на нашу думку, може бути створений для кожної конкретної спеціалізації, але будь-який фахівець, підготовлений у сучасній вищій школі, зобов'язаний комунікувати на високому рівні, тобто логічно висловлюватись, підтримувати бесіду (запитувати, слухати, відповідати), аналізувати, доводити свою думку, обгрунтовувати, переконувати, вмотивовувати, аргументувати, спростовувати, заперечувати, відхиляти, оцінювати, робити висновки, вибирати стиль поведінки, види і форми спілкування відповідно до конкретної ситуації.

Комунікативна компетентність будь-якого фахівця, на наше переконання, передбачає володіння такими навичками:

- урахування принципів спілкування - найзагальніших вимог до учасників процесу лінгвістичної взаємодії (достатність необхідної інформації, ііі істинність, доцільність, чіткість тощо);

- дотримання правил спілкування - загальноприйнятих вимог до ведення розмови, аргументації, уміння використовувати конкретні умови комунікації;

- обрання та застосування різних комунікативних стратегій (вибір найбільш дієвих глобальних складників спілкування у визначеному порядку відповідно до комунікативних намірів) і тактик (раптовість, провокація, апеляція до авторитетів, гумор тощо) для досягнення позитивного результату;

- $\quad$ створення текстів різних жанрів усного і писемного мовлення, у тому числі офіційно-ділового стилю та доцільне їх використання;

- аналіз та реферування текстів різних жанрів, підготовка аналітичних оглядів, довідок, висновків на основі опрацьованих текстів;

- застосування монологічного та діалогічного (полілогічного) мовлення фахового спрямування (доповідь, звіт, промова, дискусія);

- дотримання норм української літературної мови в офіційному спілкуванні (участь в офіційних заходах, корпоративне спілкування тощо);

- спілкування державною мовою на засадах соціальної та міжособистісної етики, моделювання комунікативної поведінки відповідно до ситуації.

Правильним і своєчасним рішенням було введення обов’язкової дисципліни «Українська мова (за професійним спрямуванням)», що передбачає поглиблення, удосконалення, систематизацію знань, умінь, навичок мовного послуговування з огляду на професійну сферу.

Програма дисципліни створена на основі поставлених завдань та вдало поєднує елементи культури мови, стилістики, риторики, термінології тощо і має на меті: підвищення рівня загальномовної підготовки, мовної грамотності, комунікативної компетентності студентів, практичне оволодіння основами офіційно-ділового, наукового, розмовного стилів української літературної мови, що забезпечить професійне спілкування на належному мовному рівні. У разі проведення занять на високому науково-методичному рівні, продуктивного використання засобів, методів викладання можна досягти неабиякого результату щодо удосконалення мовної та комунікативної компетентності майбутніх фахівців. Студенти розширюють знання про українську літературну мову як мову 
професійного спілкування, аналізують основні функції мови та мовні норми, визначають нормативно-правову базу утвердження української мови як державної в Україні. Тема, присвячена основам культури української фахової мови, допоможе розкрити значення понять «культура мови» i «культура мовлення», схарактеризувати комунікативні ознаки якісного мовлення, виокремити поняття «мовний», «мовленнєвий», «спілкувальний етикет», 3'ясувати роль і значення словників у підвищенні мовної культури особистості.

Дуже важливими є заняття, які торкаються питань риторики. Риторика як навчальна дисципліна необхідна в усіх сферах людської діяльності, вона $є$ наукою і мистецтвом «переконуючої комунікації, що становить фундамент професіоналізму вчителя, політика, юриста, менеджера та багатьох інших гуманітарних кадрів нової України» (Сагач, 1993, с. 3). Професійне володіння ораторською майстерністю стає в сучасному світі невід'ємним елементом підготовки фахівців у будь-якій професійній царині: дипломатії, юриспруденції, педагогіці, медицині, торгівлі, мистецтвознавстві, психології, для роботи в соціальній сфері (Вандишев, 2003, с. 238).

Традиційно риторику сприймають як науку про красномовство, однак у системі професійної освіти вона передбачає удосконалення мисленнєво-мовленнєвої діяльності, спрямованої на переконання, досягнення мети у процесі мовної комунікації, набуття практичних навичок укладання текстів виступів і їх проголошення, удосконалення культури мовлення, підготовка до організації ефективного спілкування у професійній діяльності. Звідси випливають важливі завдання:

- формування вмінь і навичок застосування вербальних і невербальних засобів комунікації, логічних, психологічних, етичних, літературних прийомів у мові та спілкуванні;

- опанування методики підготовки промови (пошук і композиційна будова матеріалу);

- ознайомлення з основами мистецтва колективного публічного спілкування, зокрема формування полемічної майстерності;

- розвиток потреби постійного духовного збагачення та прагнення до професійного вдосконалення тощо.

Виконання цих завдань забезпечить чітке і правильне розуміння ролі ораторського мистецтва у професійній діяльності; правильне використання різних мовних засобів відповідно до комунікативних намірів; влучне висловлювання думки для успішного розв'язання завдань у професійній діяльності; володіння методом риторичного аналізу текстів; самостійне продукування текстів різних типів промов; вироблення критичного ставлення до власного мовлення і суспільної мовної практики; формування духовного світу особистості шляхом засвоєння класичної та національної риторичної спадщини давнього й сучасного світу шляхом прилучення через мову до культурних надбань рідного народу й людства взагалі тощо.

Тема «Науковий стиль і його засоби у професійному спілкуванні» передбачає навчити студентів аналізувати наукові, науково-популярні тексти на лексичному, лексико-семантичному, стилістичному і граматичному рівнях, редагувати, скорочувати (компресія) тексти, конструювати елементи висловлювання з урахуванням запропонованої мовленнєвої ситуації. Правильно підібраний текст допоможе сформувати уміння спочатку правильно складати вторинні наукові тексти (конспект, анотацію, реферат), а потім підготуватися до написання власного наукового тексту, наприклад, дипломної роботи. Укладаючи конспект, студенти розуміють структуру наукового тексту й особливості його будови, усвідомлюють необхідність правильно скорочувати слова, написати план і виконати певну компресію тексту (Шевчук, \& Клименко, 2011).

Отже, опанувавши матеріал дисципліни «Українська мова (за професійним спрямуванням)», студенти повинні вміти:

- правильно використовувати різні мовні засоби відповідно до комунікативних намірів; влучно висловлювати думки для успішного розв'язання проблем і завдань у професійній діяльності;

- сприймати, відтворювати, редагувати тексти офіційно-ділового й наукового стилів;

- оперувати фаховою термінологією, перекладати наукові тексти.

- скорочувати та створювати наукові тексти професійного спрямування, складати план, конспект, реферат тощо, робити необхідні нотатки, виписки відповідно до поставленої мети;

- укладати різні типи документів, правильно добираючи мовні засоби, що репрезентують їх специфіку;

- послуговуватися лексикографічними джерелами (словниками) та іншою допоміжною довідковою літературою, необхідною для самостійного вдосконалення мовної культури.

Будь-який фахівець зобов'язаний доцільно послуговуватися мовними засобами різних рівнів, що забезпечить комунікативну досконалість мовлення.

Нормативна навчальна дисципліна «Українська мова (за професійним спрямуванням)» є складовою циклу професійної підготовки фахівців освітньо-кваліфікаційного рівня «бакалавр», є базовою для вивчення всіх наступних спеціальних дисциплін. Дисципліна забезпечує формування кваліфікованих, грамотних, мовно компетентних фахівців, які б досконало володіли українською літературною мовою у професійній сфері.

Ми поділяємо думку науковців (Тур, 2016), які стверджують необхідність створення моделі формування комунікативної компетентності майбутніх фахівців. Під час проектування такої моделі необхідно враховувати професійну компетентність викладача, наявність об’єктивних факторів - соціальне замовлення вищої професійної школи, Державний освітній стандарт вищої професійної освіти, цілісну освітню сферу вишу, рівень комунікативної компетентності студентів.

За Тур (2016), проектування концептуальної моделі формування комунікативної компетентності майбутніх фахівців із документознавства та інформаційної діяльності підпорядковано такій логіці: визначення меж моделі; визначення мети й завдань, окреслення наукових підходів; вибір компонентів комунікативної компетентності; 3'ясування етапів процесу формування комунікативної компетентності; визначення організаційно-педагогічних умов та ін. Дослідником обрано такі основні компоненти - цільовий, технологічний, аналітико-результативний, виконання яких, на його думку, буде результатом досягнення реалізації моделі, тобто перехід на більш високий рівень комунікативної компетентності. 
Висновок. Узагальнюючи сказане, ми дійшли висновку, що на сучасному етапі розвитку суспільства важливо сформувати успішну, освічену людину, здатну ухвалювати відповідальні рішення, критично мислити, творчо виконувати виробничі завдання - тобто особистість з високим рівнем мовної та комунікативної компетентності, яка володіє сукупністю знань, умінь і навичок, що забезпечить бездоганне виконання професійних обов'язків, потребу в самопізнанні, саморозвитку, самореалізації, уміння об’єктивно розв'язувати життєві проблеми, соціально адаптуватися.

\section{Список використаних джерел}

Бацевич, Ф. С. (2004). Основи комунікативної лінгвістики. Київ: Академія.

Білогорка, М., \& Мороз, Т. (2015). Шляхи формування мовної компетентності особистості: наук.-метод. підхід. Педагогіка, 11, 222-228.

Вандишев, В. М. (2003). Риторика: екскурс в історію вчень і понять. Київ: Кондор.

Гриневич, Л., Елькін, О., Калашнікова, С., Коберник, І., Ковтунець, В. ... Грищенко, М. (Ред.). (2017). Нова Концепиія украӥнської иколи. Взято з http://www.oblosvita.mk.ua/attachments/article/3935/.

Романовський, О., Романовська, Ю. \& Романовська, О (2009). Мовна компетентність як необхідна складова виховання освіченого та інтелігентного українця. Вища школа, 7, 88-98.

Сагач, Г. М. (1993). Золотослів. Київ: Райдуга.

Тур, О. (2006). Формування комунікативної компетентності в прочесі підготовки фахівців із документознавства та інформачійної діяльності. Полтава: ПолтНТУ.

Шевчук, С. В. \& Клименко, І. В. (2011). Украйнська мова за професійним спрямуванням. Київ: Алерта.

\section{References}

Bacevych, F. S. (2004). Osnovy komunikatyvnoji linghvistyky [Basics of communicative linguistics]. Kyiv: Akademija [in Ukrainian].

Biloghorka, M. \& Moroz, T. (2015). Shljakhy formuvannja movnoji kompetentnosti osobystosti: naukovo-metodychnyj pidkhid [Ways of forming the language competence of the individual: scientific methodological approach]. Pedaghoghika [Pedagogyka], 11, 222-228 [in Ukrainian].

Vandyshev, V. M. (2003). Rytoryka: ekskurs v istoriju vchenj i ponjatj [Rhetoric: An excursion into the history of doctrines and concepts]. Kyiv: Kondor [in Ukrainian].

Ghrynevych, L., Eljkin, O., Kalashnikova, S., Kobernyk, I., Kovtunecj, V. .. \& Ghryshhenko, M. (Eds.). (2017). Nova Koncepcija ukrajinsjkoji shkoly [New Concept of the Ukrainian School]. Retrieved from: http://www.oblosvita.mk.ua/attachments/article/3935/ [in Ukrainian].

Romanovsjkyj, O., \& Romanovsjka, O. (2009). Movna kompetentnistj jak neobkhidna skladova vykhovannja osvichenogho ta intelighentnogho ukrajincja [Language competence as a necessary component of education of an enlightened and intelligent Ukrainian]. Vyshha shkola [High school], 7, 88-98 [in Ukrainian].

Saghach, Gh. M. (1993). Zolotosliv [Golden words]. Kyiv: Rajdugha [in Ukrainian].

Tur, O. (2006). Formuvannja komunikatyvnoji kompetentnosti v procesi pidghotovky fakhivciv iz dokumentoznavstva ta informacijnoji dijaljnosti [Formation of communicative competence in the process of preparation of specialists in documentation and information activities]. Poltava: PoltNTU [in Ukrainian].

Shevchuk, S. V., \& Klymenko, I. V. (2011). Ukrajinsjka mova za profesijnym sprjamuvannjam [Ukrainian language in professional direction]. Kyiv: Alerta [in Ukrainian]. 


\title{
ISAIENKO T., MIZINA O.
}

Poltava National Technical Yuri Kondratyuk University

\section{IMPROVEMENT OF LANGUAGE AND COMMUNICATIVE PROFICIENCY OF FUTURE SPECIALISTS}

Ways of improving the language and communication proficiency of future specialists in higher education have been revealed and analyzed in the research article.

It was noted that in organization of educational process at higher educational establishments that stipulates both vocational and educational component, the content of the future specialist's professional grammar has been taken into account in order to be approximate as much as possible to modern production requirements.

The main components of the job profile diagram of young specialists in any field of national economy have been identified.

The place and role of language and communicative proficiency for education of modern specialists of various specialties and importance of having necessary skills have been identified. Requirements for communicative proficiency level of future specialist have been indicated.

It has been proved that it is possible to direct the educational process in accordance with the goal by selecting the necessary means and creation of certain conditions.

The significance of the subject "Ukrainian (for specific purposes)", which provides deepening, improvement, systematization of knowledge, skills, language skills, taking into account professional field that successfully combines elements of the speech culture, stylistics, rhetoric, terminology, and the like has been revealed.

The importance of classes with elements of rhetoric as a science of persuasive communication, necessary in all spheres of human activity as the basis of a specialist's professionalism in any industry has been indicated.

The need for continuous improvement of language and communicative proficiency of individual as a necessary component for modern specialist training has been proved.

Keywords: job profile diagram; language proficiency; communicative proficiency; higher educational establishment; educational process

Стаття надійшла до редакції 15.01.2019 p.

УДК 373.5.04:316.61]:81

DOI: https://doi.org/10.33989/2075-146x.2019.23.183214

OLENA KAZACHINER

Kharkiv academy of postgraduate education, Kharkiv, Ukraine

\section{PECULIARITIES OF MASTERING LANGUAGE MATERIAL BY CHILDREN WITH DOWN SYNDROME}

\begin{abstract}
The article reveals peculiarities of language learning by children with Down syndrome. Children with Down's syndrome frequently have speech and language impairments although the nature of their language learning difficulties can differ substantially between individuals. Both hearing loss and delayed development contribute to language learning. Children show specific strengths in receptive vocabulary. Sign and gesture can support vocabulary learning and visual scaffolds support language learning. Enhanced verbal environments help to develop verbal abilities. While understanding precedes expressive ability for all children, this balance is frequently larger than usual and is sometimes vast, which in some cases leads to children's understanding and other abilities being underestimated. Individuals are likely to have difficulty expressing their thoughts and feelings. Most learners have significant speech, language and communication needs throughout childhood. Activities to support the full range of speech, language and communication needs that individual children experience should be directed by a speech and language therapist.

The script of the workshop of the same name for philology teachers, which can be conducted in extra-curricular time in the system of postgraduate education, has been worked out.
\end{abstract}

Keywords: linguistic material; mastery of linguistic material; child with Down syndrome; philology teacher; postgraduate education.

Introduction. Down syndrome (DS) is a genetic disorder caused by a failure of the 21 st chromosome to separate during cell division and thus changes the development of the body, which includes brain development as well. Due to its specific occurrence, it is not considered a disease but a permanent lifetime condition of a person. This condition is characterized by several psychophysical characteristics which are mostly common for all persons with Down syndrome: poor muscle tone, slanted eyes, round face with a flat profile, short hands, low cognitive functioning.

These characteristics are also accompanied with specific disabilities such as auditory, visual, tactile, speech, language and communication difficulties. However, it is important to know that there is no universal rule or any sign by which the level of disabilities or difficulties in persons with Down syndrome can be predicted.

Moreover, the range of diversity related to mental capacities, behaviour and developmental abilities in general is quite large. Each child, each person with Down syndrome is different. Only discovery and knowledge about specific needs and 